\title{
1. Introduction to The Governance of Labour Administration
}

\section{Jason Heyes, Ludek Rychly, Maria Gavris and Maria Luz Vega Ruiz}

\subsection{INTRODUCTION}

Analyses of the role of government in regulating the labour market tend to focus on the content and consequences of government policies and the legal framework within which employment relationships are established. Labour administration has tended to receive much less attention, yet well-resourced and well-managed public bodies are of critical importance if labour market challenges are to be addressed and the effectiveness of policy enhanced. Labour administration is defined by the International Labour Organization's (ILO) Labour Administration Convention, 1978 (No. 150)' as 'public administration activities in the field of national labour policy'. This includes institutions, activities and outcomes across the entire field of labour policy, including employment policy, labour law, social protection and industrial relations. These functions are carried out by 'national systems of labour administration', a term that refers to 'all public administration bodies responsible for and/or engaged in labour administration - whether they are ministerial departments or public agencies, including parastatal and regional or local agencies or any other form of decentralized administration - and any institutional framework for the coordination of the activities of such bodies and for consultation with and participation by employers and workers and their organizations'. ${ }^{2}$ Ministries of labour (or their functional equivalents) are typically responsible for the development of labour policies, sometimes with the involvement of other government departments, and are also responsible for bodies that implement and enforce policies. The most important bodies are those responsible for the enforcement of employment rights and laws relating to occupational safety and health (OSH) (generally referred to as labour inspectorates), public employment services (PES) that provide support for workers seeking jobs and help to connect them to employers with jobs vacancies, and bodies concerned with individual and collective dispute resolution. The effectiveness of national 
labour policies is fundamentally dependent on how these labour administration bodies and their activities are organized and resourced.

This book represents a response and contribution to the developing international agenda relating to effective governance and its role in encouraging economic and social development and protecting workers. In a broad sense, governance refers to 'patterns of rule' (Bevir, 2009: 3) that may operate at and across levels ranging from the local to the international. Governance is, however, a widely debated and notoriously elastic concept (e.g. Rhodes, 1996; Kjær, 2004; 6, 2015). Following van Berkel et al. (2011: 2), our use of the term is in keeping with that of Kooiman and Bavinck (2005: 17) who refer to governance as the "whole of public and private interactions taken to solve societal problems and create social opportunities'. ${ }^{3}$

Following the adoption of the United Nations (UN) Sustainable Development Goals in 2015, the organization set out to identify the most relevant factors impacting on the effectiveness of public administration. Based on recommendations by leading experts on public administration (CEPA - the UN's Committee of Experts on Public Administration) the Economic and Social Council (ECOSOC) of the UN adopted in July 201811 principles of effective governance for sustainable development, ${ }^{4}$ grouped under pillars of effectiveness, accountability and inclusiveness. Effectiveness encompasses competence, sound policy making and collaboration. Accountability involves ensuring integrity, transparency and independent oversight while inclusiveness involves leaving no one behind, non-discrimination, participation, subsidiarity and intergenerational equity.

Effective governance is regarded by the UN as a necessary precondition for creating spaces in which to pursue a reduction in poverty and sustainable human development (in the Sustainable Development Goals (SDGs), 2030). ${ }^{5}$ In this respect, the ILO's objective and its mandate since its creation in 1919 is to protect workers from unacceptable working conditions and improve living standards in general; this is more relevant than ever before. Hence the launch in 2015 of its centenary initiative on the Future of Work, ${ }^{6}$ seeking to offer new responses and innovative recommendations in an uncertain context, but always within the framework of its constitutional mandate.

The key question that this book seeks to address is how can labour administration contribute to effective governance? The book answers this question by analysing examples from developed and emerging economies. Each contribution examines a labour administration problem that relates to at least one of the three pillars of effective governance, enabling a better understanding of governance challenges as they relate to labour administration and how they might be addressed. Most chapters focus on the regulatory function ${ }^{7}$ of labour administration, particularly in relation to the enforcement of labour laws. However, attention is also given to the public management aspects of labour 
administration, such as methods of performance management and the coordination of different labour administration bodies.

\subsection{GOVERNANCE CHALLENGES FOR LABOUR ADMINISTRATION}

The pillars of effectiveness, accountability and inclusion raise a number of issues for labour administration.

Effectiveness is a core concern of the ILO Labour Administration Convention, 1978 (No. 150), which declares that the staff of labour administration bodies should have the status, the material means and the financial resources necessary for the effective performance of their duties. Effectiveness implies that policy makers should have access to accurate and reliable evidence that can inform the content of policy measures and allow the impact of policies to be measured. It also implies that labour administration bodies should have the means to implement policies effectively. Mechanisms are needed to ensure that employers comply with legislation relating to employment rights and occupational safety and health (OSH) and this is likely to require that enforcement agencies have the ability to coordinate their activities effectively. For example, the ability of public authorities to address problems such as disguised employment, dependent self-employment and employers' non-compliance with minimum wage legislation might be enhanced by cooperation and information sharing by labour inspectorates and bodies responsible for tax and social security (Vega, 2013; Heyes and Hastings, 2017). A further important consideration is the fact that policy responsibilities relating to labour issues are sometimes distributed across different levels of government (national, regional and local - see Sarkar, this volume) or two or more government departments, which implies a need for effective information sharing and horizontal and/or vertical coordination in order to ensure policy coherence (Heyes and Rychly, 2013). Issues of resourcing are also important. Labour administration bodies need adequate budgets, the ability to recruit an adequate number of appropriately trained personnel, and support for new technologies.

Discussion of the second pillar of UN Governance principles, accountability, cannot be separated from discussion of effectiveness since the accountability of administrators and administrations cannot be properly established without the capacity to measure performance. Accountability implies, among other things, that labour administration bodies are able to provide clear and transparent information to ministers and parent departments, that their decisions can be challenged and complaints lodged, and that the public has access to information about the role and performance of labour administration and their own rights. The accountability of individuals is also important; for example, there is a risk that low-paid labour inspectors will be tempted to engage in 
corrupt practices (ILO, 2011). Considerations relating to the accountability of labour administration include the widespread use of performance measures in public administration (Heinrich, 2012; Hammerschmid et al., 2016), which can potentially help to ensure that the actions taken by those who work for labour administration bodies are aligned with strategic and operational objectives. Where labour ministries and other labour administration bodies are able to measure accurately the performance of sub-units (e.g. departments, local labour inspectorates, local employment offices), this can provide a basis for regular assessment of progress towards goals and enable corrective action to take place. Such information can potentially also make labour administration more transparent, to the extent that performance data may be shared with different audiences, which might include the general public (e.g. in the form of annual reports made available on government websites). Information relating to performance can also contribute towards assessments of the effectiveness of labour administration. ${ }^{8}$

The third pillar, inclusiveness, is particularly relevant for labour administration as it reflects its very purpose and nature. The mandate of a ministry of labour is concerned with the protection of vulnerable groups of people, particularly if it is also responsible for social security. Inclusiveness raises issues that relate to the coverage of employment rights and social security entitlements and the extent to which different groups (e.g. migrant and non-migrant workers) have different entitlements. The emphasis on participation also raises questions about how and to what extent employer bodies and trade unions are involved in the elaboration of labour policies and, potentially, in their implementation. In many countries, participation primarily takes place through tri-partite social dialogue, although in some countries employers and trade unions have some responsibility for overseeing policy delivery, for example in areas such as vocational education and training and pensions. Where engaged in earnest, social dialogue can lead to shared understandings of economic and social challenges and ensure that the concerns of workers and employers are at least considered when policy is being formulated.

Achieving good governance in labour administration is, however, problematic in a number of respects. Some of the problems are relatively new, while others are relatively long-standing. ${ }^{9}$

One important long-standing challenge is that labour administration bodies are often under-resourced and under-staffed. This is particularly the case in developing economies (ILO, 2011: 18), but even in developed economies staffing can be insufficient. Difficulties also often exist in relation to access to reliable and objective information that accurately captures labour market developments. Resource constraints can inhibit the regular collection of labour market information and other socio-economic data through representative national surveys. Even developed countries typically lack adequate 
information about important employment phenomena, such as dependent self-employment (ILO, 2016: 98).

Information gaps and resource constraints negatively impact the ability of labour administration bodies to fulfil their mandates. For example, the ability of labour inspectorates to detect violations of labour and take action to ensure compliance pre-supposes the existence of effective reporting mechanisms, availability of information about businesses and their locations, the ability to travel to locations and the existence of effective case management systems. A further difficulty is that certain types of work are beyond the remit of labour inspectorates or employment law. For example, the regulation of domestic work can be difficult because the need for labour inspectors to access a household that is not the property of the domestic worker can come into conflict with the right to privacy, which is often enshrined in national legislation. More generally, work in the informal economy remains widespread in many countries and according to a recent ILO study (ILO, 2018), more than 61 per cent of the world's employed population are in informal employment. Although there is broad acceptance that the ILO's eight fundamental conventions apply to the informal economy, ${ }^{10}$ workers in the informal economy are often beyond the ambit of labour administration and lack social protections and labour rights (ILO, 2013).

A further long-standing challenge, which particularly relates to inclusive governance, is that trade unions and employer organizations rarely encompass the majority of workers and businesses, a problem which is being exacerbated by declining trade union membership (Hayter and Gammarano, 2015). Moreover, although social dialogue fora are widespread in both developed and developing countries, ${ }^{11}$ impact on national policies are relatively rare. The mere existence of economic and social councils and similar bodies does not necessarily signal a strong commitment to social dialogue (see Papadakis, this volume).

These long-standing problems have been compounded by more recent economic and social developments. Although resources for labour administration were increased in the initial stages of the financial crisis that erupted in 2007-08, the austerity measures that were subsequently introduced in many countries were associated with cuts in public funding that fell heavily on labour administration bodies (Heyes, 2011, 2013; Vega, 2013), leading to job cuts, increased workloads for remaining staff and increased difficulty in carrying out activities such as labour inspections. Many labour ministries and associated agencies have therefore been confronted with the challenge of trying to achieve 'more' for 'less'. The adoption of austerity measures also appears to have given further impetus to a centralization of previously separate functions through a merging of labour administration bodies, a trend that was apparent before the financial crisis, particularly in relation to employment 
services (Gavris and Heyes, 2019). ${ }^{12}$ In Europe, centralization reflects a wider dynamic in European public administration, where fiscal retrenchment and centralization have been the predominant forms of response to the crisis (Randma-Liiv and Kickert, 2017). ${ }^{13}$ Furthermore, in some countries, ministries of finance or the economy have come to play a more substantial role in labour matters and their power has increased vis-à-vis that of labour ministries (Rychly, 2013; Gavris and Heyes, 2019). There are also cases of responsibility for labour issues being transferred to ministries that are primarily responsible for the economy. An example is provided by Hungary, where in 2015 the National Labour Office was dissolved and some of its functions, including labour inspection activities, were transferred to the Ministry of the National Economy.

Although social dialogue played a vital role in many countries' responses to the financial crisis, in some countries it was adversely affected by the aftermath. This occurred primarily in the countries hardest hit by the crisis, such as Spain and Ireland, where external conditions attached to bailout packages reduced domestic room for manoeuvre as well as time frames for consultation with social partners (Hyman, 2013; Papadakis and Ghellab, 2014; Gavris and Heyes, 2019). The involvement of social partners in labour administration has also been weakened by changes in labour market regulation. In Germany, for example, social partners remain on the governing board of the PES (Bundesagentur für Arbeit) but their role was eroded during the early 2000s, when responsibility for the administering of unemployment assistance payments for the long-term unemployed was transferred from the Bundesagentur für Arbeit to newly created jobcentres in which the social partners play no role (Weishaupt, 2011).

A further development has been the growth in Non-Standard Employment (NSE) that has been witnessed in many countries in the wake of the financial crisis (ILO, 2016). NSE encompasses temporary employment, part-time work, temporary agency work and casual work, which are all well-established types of employment. Alongside these, there has been a rapid expansion in 'on demand' or 'gig work', enabled by labour-based online platforms (de Stefano, 2016), and forms of part-time work that involve workers being 'on-call', with no obligation on the part of employers to provide a specific number of hours of work or any work at all (so-called 'zero hours' contracts). The growth in NSE has led to an increase in the number of workers in precarious work, that is, "work that is uncertain, unstable, and insecure and in which employees bear the risks of work (as opposed to businesses or the government) and receive limited social benefits and statutory entitlements' (Kalleberg, 2018: 3 , italics in original). Workers in some forms of NSE (e.g. gig work) lack the protections that labour laws extend to workers in standard employment and are also inadequately protected by social insurance systems (Countouris and 
Freedland, 2013; Eurofound, 2016; Schippers, 2019). A pressing question for the future of work is how can employment regulation and social protection be made more inclusive ${ }^{14}$ (Rubery, 2015)?

At the time of writing, the COVID-19 pandemic is presenting a further substantial challenge to labour administration. There has been a need to develop and implement policies and measures to prevent job losses and protect businesses and the incomes of workers who have been unable to work because of government restrictions. ${ }^{15}$ The inspection of workplaces has become more hazardous for labour inspectorates while the number of people working remotely has increased substantially. Those workers who remain at the workplace face increased physical and mental health risks. The impacts of COVID-19 have also reinforced existing divisions and disadvantages among the workforce. For example, migrant workers tend to be over-represented in some of the sectors that have been hit hardest by the crisis (e.g. hospitality, domestic work) and also face increased health-related risks given that they are often employed in jobs that have become 'essential' (e.g. in health care, agriculture and agro-food processing) (ILO, 2020b).

The world of work has therefore become more heterogeneous and, for many, unpredictable and risky. Conventional labour relations coexist with more flexible (and less protected) ways of working and informal work situations, albeit to varying degrees. The economic and social context has also become more challenging: economic growth remains sluggish (a problem exacerbated by the impact of COVID-19), global value chains are becoming more complex and integrated with both off-shoring and re-shoring taking place, demographic changes stemming from migration and population ageing are occurring in addition to technological changes. ${ }^{16}$ These developments are prompting questions about the future of work, including what will be the future relationship between humans and machines at work, will artificial intelligence (AI) and automation lead to widespread job destruction, how will climate change affect jobs and how can social protection be made more inclusive? It is likely that good governance will require the adoption of an holistic focus that goes beyond the labour market and encompasses other social and economic relationships. ${ }^{17}$ This will not only involve legislative adjustments and measures to reduce segmentation and tackle inequality, but also reforms that are comprehensive enough to guarantee the minimum protections while maintaining the institutions that support them.

\subsection{OVERVIEW OF THE BOOK}

The contributions to the book provide valuable insights into how governance challenges relating to labour administration are being met in different countries and different areas of activity (e.g. labour inspection, programme 
evaluation). The contributors are members of a labour administration network established by the ILO and Sheffield University Management School in the UK to facilitate the investigation and discussion of labour administration issues, bringing together ILO officials, high-level public servants and academic researchers from a number of ILO member countries. Between 2013 and 2019, network meetings were held in Turin, Prague and Sheffield and the knowledge exchange that took place has strongly informed the book's content.

This book is organized into two substantive sections. The first three chapters analyse key developments in labour administration, taking an international perspective. The second section comprises studies of labour administration developments within specific countries. Together, these chapters address issues related to the three governance principles established by the UN. All chapters address more than one pillar. In relation to effectiveness, contributors examine issues such as capacity and management of labour inspectorates, the uses of ICT in labour inspection, coordination and cooperation by labour administration bodies, innovative approaches to regulating work and employment and the evaluation of policy measures. In relation to accountability, there are chapters that examine the role of performance management in labour administration, the uses of data and engagement with the public. Finally, with regard to inclusion, contributors discuss issues such as the extension of labour administration to the informal economy, government policy in relation to migrant workers and the important role played by social dialogue in labour administration.

The book's first three chapters analyse developments in labour administration taking an international perspective. The first of these chapters, which is by José-Luis Daza, provides a detailed historical analysis of key developments in labour administration and how these have been shaped by political, economic and social forces. Daza shows how cuts in public spending during economic downturns have influenced the organization and effectiveness of labour administration. He also examines how labour administration has been affected by wider developments in public administration, such as the adoption of New Public Management principles, and how it has responded to developments in the labour market, such as the growth in non-standard employment.

Daza's chapter emphasizes the important roles that employer and trade union organizations can play in relation to labour administration. This theme is developed further in Chapter 3, which is by Kostas Papadakis. Papadakis emphasizes the centrality of social dialogue to the ILO's perspective on how labour-related matters should be addressed. However, tri-partite and bi-partite social dialogue face serious challenges in many parts of the world. These include falling membership among employers' organizations and trade unions, a growth in new forms of work involving workers who often lack collective representation, growing inequality and a 'decline in the use of forms of social 
dialogue that produce binding commitments, such as collective bargaining and processes that lead to the conclusion of social pacts' (Papadakis, this volume, p. 45). In some countries, basic necessary preconditions for social dialogue, such as political stability and freedom of association, do not exist. Nevertheless, Papadakis' chapter demonstrates the strong potential for social dialogue to contribute to the effectiveness and inclusiveness of labour administration. For example, in many countries social dialogue played a vital role in national responses to the financial crisis and is, at the time of writing, also making an important contribution to the development of responses to the COVID-19 pandemic and measures to support firms and workers.

The final chapter with an international perspective, Chapter 4, is by Anna Galazka, who discusses the use of new technologies in labour administration and how they have affected the ways in which agencies perform their activities. Drawing on survey data collected from labour administration bodies in more than 80 ILO member countries, Galazka analyses the extent of ICT use in labour administration and also discusses specific examples of how ICT has enabled improvements in the accountability and effectiveness of labour administration bodies. For example, in the field of labour inspection, Galazka shows that ICT has the potential to partly compensate for declining resources by enabling inspection activities to become more data-driven, risk-based, better targeted and more strategic. By combining and sharing their data resources, labour law, taxation and social security enforcement bodies in some countries are also using ICT to tackle problems associated with certain forms of atypical employment, such as disguised employment relationships.

The remaining chapters of the book examine labour administration developments in specific countries. Most of the chapters focus their attention on particular issues, such as the use of ICT, performance management, policy evaluation and enforcement activities. Evidence on what practices and approaches are effective, accountable and inclusive and which are not in relation to labour administration can come only from analysing different circumstances and environments. For this reason, the national studies include a mix of developed and emerging economies.

In Chapter 5, Roberto Pires discusses the challenges to labour inspectorates presented by the growth in non-standard forms of employment and argues that new strategies of governance are required to address these challenges. Focusing on the experience of Brazil, Pires analyses experimental approaches to regulation that have been developed by public enforcement bodies in partnership with other actors, such as trade unions and non-governmental organizations (NGOs). He emphasizes that the effectiveness of inspection is not only influenced by institutional arrangements and resourcing of inspectorates, but by the relationships that exist between the various actors that play a role, or potential role, in protecting workers. Pires highlights the various ways in 
which government and non-government actors have collaborated in Brazil and how these collaborations have resulted in more effective regulation of atypical employment, thereby extending the coverage of labour inspection and making it more inclusive. He also emphasizes, however, that for collaboration to become more widespread and sustainable, there is a need for incentives, mechanisms to ensure accountability and 'management techniques, which embrace the idea that the solution to complex problems often requires a great deal of collective action (within government and across non-government agents)'.

In Chapter 6, Virginie Forest examines the 'Strong Ministry of Labour' reform, which was launched in France in 2012 and has been in force since 1 January 2015. The reform has built on earlier reforms of France's labour inspection system that took place between 2006 and 2009 and which in part reflected attempts to introduce management and performance principles associated with the New Public Management. The more recent reforms have included a comprehensive geographical and managerial reorganization of the labour inspection system; removing the distinction between labour auditors (previously responsible for enforcement activity in relation to small enterprises) and labour inspectors (previously responsible only for larger enterprises); and an expansion and strengthening of inspection officials' power to impose administrative penalties, in place of treating violations (e.g. non-compliance with minimum wage requirements) as matters for criminal prosecution. Although intended to improve coordination and increase the effectiveness and efficiency of the labour inspection system, the reforms have encountered opposition from trade unions. Forest also claims that the reforms have yet to achieve their intended objective of ensuring more streamlined working practices in the labour inspection system, highlighting the difficulties inherent in altering established organizational cultures.

Chapter 7, which is by Timo Weishaupt, analyses the emergence of a political consensus in Germany concerning the desirability of a statutory national minimum wage, the introduction of which led to an effective extension of the scope of labour market regulation. Weishaupt shows how this development reflected concerns linked to the growth in low-waged work, a contraction of collective bargaining coverage and increasing inequality. He also discusses the various ways in which compliance with minimum wage regulations is enforced, describing the activities of public bodies and drawing attention to cooperation between the principal enforcement body, the Financial Monitoring Unit (FKS), and the German social partners, which have formed 'federal alliances against illegal employment' in industries including construction, transport and trucking, industrial cleaning and hairdressing. Weishaupt also emphasizes the need for regular inspections and close cooperation between all relevant public bodies if monitoring and enforcement activities are to be effective. 
Chapter 8, which is by Kingshuk Sarkar, analyses the challenges confronting labour administration in India. These include the size of India's informal economy, which accounts for a substantial majority of workers. The application of most labour laws and related regulations in India is restricted to cases where employment relationships are in place, yet in the informal economy the existence of employment relationships is extremely hard to determine. Nevertheless, Sarkar describes how public authorities in India have attempted to extend the reach of labour administration to homeworkers and the self-employed, many of whom may be in a disguised employment relationship, and discusses the efforts that have been made to extend the coverage of social protection through the creation of an industry-specific welfare board. Sarkar also discusses the implications of declining trade union membership in India and developments affecting social dialogue. Although tri-partite consultation remains an important feature of employment relations and labour market governance in India, Sarkar warns that it appears to be becoming less influential and risks becoming a mere formality.

The question of how labour laws might be better implemented and enforced in a context of changing labour market structures and the growth in non-standard employment is further explored in Chapter 9, which is by Ryuichi Yamakawa. This chapter focuses on attempts by labour administration bodies in Japan to introduce forms of regulation aimed at improving standards by encouraging employers to act in their own self-interest. Essentially, this represents a shift from top-down regulation to forms of 'meta-regulation' (Gunningham, 2010: 135-40) intended to encourage employers to put in place controls, risk management strategies and performance measures that relate to desired policy goals. Yamakawa discusses the introduction of 'duty to provide' measures that set objectives for employers yet allow them some flexibility in how they go about meeting the objectives, increasing accountability by 'naming and shaming' employers who fail to respect employment rights and requiring them to disclose certain types of information to the public, and official certification of employer action plans aimed at improving equality, for example in relation to the employment of women. Yamakawa argues that such approaches have the potential to bring about more widespread benefits for workers than can be delivered by traditional enforcement approaches based on detecting violations of employment rights and issuing sanctions.

In Chapter 10, Sunil Chandrasiri and Ramani Gunatilaka provide an examination of efforts to modernize labour inspection in Sri Lanka. In particular, they discuss the development and implementation of an electronic labour inspection database, which was intended to bring about greater compliance with labour laws and improve the evidence base informing policies. However, they show how rigid, bureaucratic structures and decision-making processes in Sri Lanka's Department of Labour, combined with changes in leadership, low 
trust relations between senior managers and field staff and a lack of in-house IT knowledge, led to technology being implemented in an ad hoc, incomplete manner, with the result that the potential of the electronic system was unrealized. As also noted in Galazka's chapter, a lack of ICT capacity and skills can represent a serious obstacle to the effectiveness of labour administration and can lead to a potentially risky dependence of the public sector on private sector IT providers.

Chapter 11, written by Christopher King and Burt Barnow, examines developments in labour policies in the US. They describe the development of employment and training programmes at state and local levels and how policy makers have sought to involve employers in these policies and ensure that they are driven by employers' demands. They also emphasize the importance of programme evaluation in the US and its role in encouraging improvements in the effectiveness of programmes and the accountability of policy makers and government officials. Performance improvements are facilitated by a functional and extensive science-policy interface, which provides policy makers and programme providers with valuable feedback on the impact of policy measures. King and Barnow also discuss the enforcement of labour rights in the US, focusing on the attempts made during the Obama administration to make enforcement more proactive and effective.

In Chapter 12, Judith Czepek discusses the development of Germany's migration policy over time, showing how policy makers have tailored migration policy in attempts to meet the labour supply requirements of German employers. However, she also argues that continuity in migration policy, including tight restrictions relating to migrants from non-European Union countries combined with 'strategic liberalization' for workers with certain skills, reflects Germany's consensus-oriented political system and political compromises that also balance the interests of employers and trade unions. Furthermore, labour market policies, mainly consisting of non-tailored active labour market programmes, have not been sufficient to assist relatively low-qualified job seekers lacking German language skills, with negative consequences for the social mobility of successive generations of migrants. Since 2015, however, policies have been implemented with the aim of improving the integration of migrants, with greater emphasis on opportunities to acquire German language skills and access vocational training. In that respect, policy towards migrant workers in Germany has become more oriented towards inclusion. Czepek also shows that the capacity to learn lessons from the past can be important in the development of more effective policies.

Finally, in Chapter 13 Robert Cameron examines the development of performance management in South Africa and explores the various problems that the Department of Labour has encountered in attempting to introduce reforms associated with the New Public Management. Cameron emphasizes that the 
system of performance management is highly developed, and mechanisms have been created to improve coordination and accountability. However, the effectiveness of labour administration in South Africa is hampered by long-standing capacity constraints, particularly in relation to staffing.

\subsection{ELEMENTS OF GOOD GOVERNANCE IN LABOUR ADMINISTRATION}

Together, the contributions to this book suggest a number of important preconditions for and enablers of good governance in labour administration:

1. Labour administration institutions in various parts of the world continue to suffer from a lack of human, financial and technical resources and national governments often fail to regard labour administration as a high priority, despite its vital role in policy delivery. It is also obvious from the contributions to this collection that an immense resource gap between industrialized and developing countries remains. The chapters that relate to emergent economies (Brazil, India, South Africa, Sri Lanka) suggest, however, that with able leaders, strong political will and clearly defined objectives, even administrations with limited resources can attain at least partial successes in modernization and improvement of their service delivery.

2. It is clear that policy makers and enforcement agencies are experimenting with new ways of bringing about compliance with labour laws and bringing more workers within the scope of employment regulation and social protection. Pires' chapter emphasizes the importance of coordinated efforts by labour inspectorates and civil society actors in addressing intractable problems such as forced labour while Yamakawa suggests that meta-regulation has the potential to bring about improvements in employer behaviours and benefit larger numbers of workers. Furthermore, Sarkar demonstrates that it is possible to extend protections to workers in the informal economy, although he acknowledges the associated difficulties.

3. A number of chapters emphasize the importance of well-managed horizontal and vertical coordination. Many labour administration issues (e.g. employment, migration, labour law enforcement) are best tackled through collaboration involving various government departments and public bodies (see the chapters by Chandrasiri and Gunatilaka, Pires, Weishaupt and Czepek). ${ }^{18}$ As Daza suggests, many administrations place coordination and integration at the heart of their agendas, especially in the field of labour inspection. Several contributors also point to the importance of 
vertical coordination between central and local authorities in dealing with challenges relating to the planning and implementation of labour policies.

4. Several contributors highlight the importance of information sharing to good governance. Proactive disclosure of information is necessary to promote good relationships with non-governmental partners, especially with organizations of employers and workers. Without shared information, especially on economy and social policy, the social dialogue fora discussed by Papadakis would not have much meaning. Sharing of data is equally necessary to promote collaboration and coordination among government departments, for example among labour inspection, prosecution, tax offices and social security administration, all of which are involved in labour law enforcement (see the chapters by Daza, Weishaupt, Forest, Chandrasiri and Gunatilaka, and Pires). It is also required among bodies regulating labour migration (Czepek).

5. The book demonstrates the importance of ICT as a major enabler of transparency and facilitator of more effective labour inspection activity and labour law enforcement. Inclusiveness and accountability in labour governance can be strengthened by improved data management and data sharing between the government, other stakeholders and the general public (Galazka) while ICT also has clear potential to enable the publicising of employment rights and facilitate more targeted and strategic enforcement by labour inspectorates and other enforcement agencies (Cameron, Galazka, Pires, Chandrasiri and Gunatilaka).

6. The principle of independent oversight raises at least two key issues in labour administration. First, several authors discuss the role of the judiciary in supervising the decisions of labour administration bodies (Czepek, Yamakawa) and even government decisions (King and Barnow). Second, the theme of compliance with labour law, which is examined by several contributors, raises issues relating to the role of labour inspection, which is supposed to have a certain degree of autonomy even within the labour administration system. ${ }^{19}$ This autonomy, and especially the scope for decisions to be taken by individual inspectors rather than being imposed from above, is a sensitive issue which is discussed in the chapter by Forest.

7. Support from representative non-governmental stakeholders is essential, and probably more important in labour administration than in any other public administration branch. Workers and employers remain the primary 'clients' of labour administration and the actors most affected by labour policies and regulations. While both employers and workers' associations may face serious representation issues, ${ }^{20}$ consulting and involving them in policy making can, as argued in the chapters by Papadakis, Weishaupt, Czepek and Pires, be beneficial for all parties as it contributes to social stability, policy coherence and public trust. As Forest's chapter suggests, 
lack of consultation and social dialogue may have a negative impact on administrative reforms as legitimacy in the eyes of workers is essential if reforms are to be accepted.

8. Decentralization of responsibilities to regional or local government, as noted by Daza, has recently been pursued in order to enhance the effectiveness of service delivery, for example in public employment services or labour inspection. It seems that the merits of decentralization versus centralization are highly contextual. While decentralization can be associated with discrepancies in policy making and implementation (Sarkar), centralization of decision making, as discussed by Forest, can also have a perverse effect of demotivating public servants, especially if they have traditionally regarded their autonomy as a foundation of their function, as has been the case with labour inspectors.

9. As Daza and Papadakis emphasize, progress in labour policies has been influenced and accelerated by crises and social conflicts. But sound policy making should not be about crisis management only; it requires that governments anticipate societal needs, innovate and adapt in order to minimize disruptions in provision of services, avoid social conflicts, support productive employment and provide for adequate social protection. To do that, labour policies should not reflect only immediate needs or short-term - and possibly populist - political interests but should build on strategic objectives. For example, the sustainability of pension schemes requires that long-term demographic and budgetary considerations are taken into account. Similarly, making the workforce ready for challenges related to digitalization and robotization is likely to require long-term investment in vocational education and training. At the same time, policy making can also benefit from constant monitoring and evaluation of interventions and programmes, as argued by King and Barnow. Strengthening the social science-policy interface can be a useful measure in this respect.

10. Labour policies are sometimes regarded as being in conflict with economic policies, particularly where the former involve stronger protections for workers. The governance of labour matters is also a politically sensitive issue as it is related to redistributive social policies that involve massive transfers of public funds to protect workers against risks. Controversies and conflicts concerning labour issues are not limited to the national level but are clearly part of interactions and competition among international organizations such as the International Monetary Fund (IMF), the World Bank, the Organisation for Economic Co-operation and Development (OECD) and the ILO. As discussed by Papadakis and Daza, since the financial crisis the IMF, World Bank and OECD have adopted a more positive perspective on the economic benefits of labour institutions and social 
policies, but Papadakis also notes that this consensus might be difficult to maintain in the longer term.

11. Effective leadership is also necessary to address problems that require collaboration among various government departments, typically issues related to employment, vocational training, migration or law enforcement (see the chapters by Chandrasiri and Gunatilaka, Pires, Weishaupt and Czepek). Enlightened leadership pursuing common objectives can help in building a culture of collaboration instead of fruitless competition based on formal mandates of individual institutions or officials. As Daza notes, many administrations place coordination and integration at the heart of their agendas, especially in the field of labour inspection. Vertical coordination between central and local authorities is also essential in planning and implementing labour policies.

\subsection{FUTURE RESEARCH DIRECTIONS}

The three governance pillars - effectiveness, accountability and inclusiveness - identified by the UN Committee of Experts of Public Administration raise a number of issues for labour administration that would benefit from further research. ${ }^{21}$ There is a need for more research on how labour administration bodies can cooperate with other public bodies, and potentially social partners and NGOs, to improve the enforcement of labour rights. Collaboration and participation are critical for sound policy making in relation to work and employment as labour policies cannot be conceived and effectively implemented without collaboration across government departments and agencies. More needs to be known about the factors that facilitate cooperation and enable joint initiatives to be sustained. ICT is potentially very important in this regard, in that it can enable information sharing, the pooling of knowledge and targeted enforcement activities based on data collected by different agencies. However, as the contributors to this book show, the management of ICT systems can be very problematic and further analysis of the capacity of governments to work with private sector providers of ICT could be beneficial.

Research also is needed on how labour administrations can best approach cross-border and global supply chains, whose activities go beyond single jurisdictions and often involve employment relationship that are hidden or replaced by commercial contracts. A better understanding is required of the particular challenges for labour administration resulting from the organization and activities of global supply chains and how those challenges might be addressed so as to improve protections for workers in producer countries.

Dialogue with non-governmental actors is very critical at all levels as its absence - as emphasized by contributors to this book - can undermine social reforms. Further research is required on the different ways in which social 
dialogue can contribute to the effectiveness, accountability and inclusivity of labour administration and the various challenges to social dialogue presented by developments such as climate change, the growth in non-standard forms of employment, AI and robotics and expanded migration flows. National governments will need to involve employers and trade unions in developing policy responses to these and other challenges (and potential opportunities) if responses are to attract widespread support and be made sustainable.

\section{NOTES}

1. The ILO Convention No. 150 on Labour Administration, (1978) (Labour Administration Convention) and the accompanying Recommendation No. 158 (1978) provide the only universally recognized conceptual framework for labour administration. Both the Convention and the Recommendation are typical 'promotional' standards; while they have a very clear normative content, they mainly provide policy guidelines and objectives that are to be actualized and implemented by means of measures adapted to national conditions.

2. https://www.ilo.org/dyn/normlex/en/f?p=NORMLEXPUB:12100:0::NO::P12100 ILO_CODE:C150 (accessed 24 August 2021).

3. Similarly, international agencies such as the UNDP, the World Bank and the OECD define governance as the exercise of authority or power with the aim of managing economic, social and political matters in a country.

4. https://publicadministration.un.org/en/Intergovernmental-Support/CEPA/ Principles-of-Effective-Governance (accessed 24 August 2021).

5. The SDGs state that 'policies must make sure that no-one is left behind'.

6. ILO. The centenary initiative relative to the future of work. International Work Conference, 104th meeting, 2015 Geneva. Report of the Director Genera, Report I.

7. Black (2001: 142) defines regulation as 'a process involving the sustained and focused attempt to alter the behaviour of others according to defined standards or purposes with the intention of producing a broadly defined outcome or outcomes'.

8. However, careful consideration is required when establishing performance measures for labour administration bodies and their staff. For example, setting targets that relate to the identification of employers that do not comply with labour laws could encourage labour inspectorates to focus on locations or types of business in which non-compliance is most easy to detect. A further example relates to the involvement of private and third sector employment service providers. Here there has been concern that efforts to incentivize performance through the use of targets linked to payments has in some cases led to providers focusing their efforts on those individuals who are easiest to get back into work while neglecting those with the greatest needs (Koeltz, 2013; Koning and Heinrich, 2013).

9. More detailed accounts of long-standing challenges are provided by the ILO (2011), Heyes and Rychly (2013) and Daza (this volume).

10. As emphasized in the ILO's Recommendation relating to Transition from the Informal to the Formal Economy, 2015 (No. 204): https://www.ilo.org/dyn/ normlex/en/f?p=1000:12100:::NO:12100:P12100_INSTRUMENT_ID:3243110 (accessed 24 August 2021).

11. Of the ILO's 187 member states, 161 ( 85 per cent) have national social dialogue institutions, not counting the mechanisms of social dialogue that focus on specific 
subjects. See https://www.ilo.org/wcmsp5/groups/public/---ed_norm/---relconf/ documents/meetingdocument/wcms_624015.pdf (accessed 24 August 2021).

12. The intensity of reform in individual countries has been influenced by policy conditionality: by whether the country had requested financial assistance from international institutions during the crisis and had been required to implement austerity in exchange. In Ireland, for instance, the objective of streamlining the administration of unemployment benefits, social assistance payments and active labour market policies - which led to the merger of a range of state agencies into the Intreo service - was explicitly set by the Troika (the European Commission, the European Central Bank and the International Monetary Fund) as part of the 2010 bailout, in the name of reducing costs and simplifying the state administrative apparatus (Köppe and MacCarthaigh, 2019; MacCarthaigh and Hardiman, 2019).

13. Examples of centralization in the sphere of labour administration include the creation of a Workplace Commission in Ireland in 2015, which brought together labour inspection services previously carried out by a range of state agencies; the reabsorption of Jobcentre Plus (PES) into its parent ministry, the Department for Work and Pensions, in the UK in 2011; the creation of Pôle emploi (PES) in France through the merger of ANPE (Agences Nationales Pour l'Emploi - Job Centres) and Assedic (Associations pour l'emploi dans l'industrie et le commerce - Associations for Employment in Industry and Commerce) in 2009; the creation of Intreo in Ireland in 2012 as a one-stop shop for jobseekers, which merged the administration of insurance-based unemployment benefit, discretionary social welfare payments and labour market activation measures; the creation of the National Labour Inspectorate in Italy in 2015 to integrate all labour inspection services previously carried out by the Ministry of Labour, INPS (National Institute for Social Security) and INAIL (National Institute for Insurance against Accidents at Work); and the merger between the Ministry of Labour and the Ministry of Health in Austria in 2018.

14. The ILO (2020a) has estimated that only 45 per cent of the global population is effectively covered by at least one social protection benefit.

15. Some countries have been able to rely on well-established programmes. For example, the long-standing kurtzarbeit short-time work scheme has proved valuable, as it did during the financial crisis.

16. The relationship between economic development and environment is increasingly evident, influencing the deterioration of the latter with the destruction of jobs with more obvious effects among the most vulnerable.

17. See SDG 17.

18. An interesting point is made by Sarkar (Chapter 8 in this volume) who insists on the necessity of collaboration between local authorities in federal states, where workers migrate between regions with different labour legislation.

19. ILO Labour Inspection Convention, 1947 (No. 81) declares that the inspection staff shall be composed of public officials whose status and conditions of service are such that they are assured of stability of employment and are independent of changes of government and of improper external influences.

20. Approximately half of the world's workforce is not protected by laws guaranteeing freedom of association and the right to bargain collectively. Implementation of these human rights is thus essential for labour administration to have representative and independent partners. 
21. The Committee's annual meeting report for 2018 noted that further research by academic networks and others could focus on the application of the principles in various development contexts, including in post-conflict situations, studies of governance failures and successes, the role of new technologies in implementing the commonly used strategies, and assessment of how best to apply the principles within existing institutions and promote them among the public sector workforce.

\section{REFERENCES}

6, P. (2015), 'If governance is everything, maybe it's nothing', in Massey, A. and Johnston, K. (eds), The International Handbook of Public Administration and Governance. Cheltenham, UK and Northampton, MA, USA: Edward Elgar, pp. 56-80.

Bevir, M. (2009), Key Concepts in Governance. London: Sage.

Black, J. (2001), 'Decentring regulation: understanding the role of regulation and self-regulation in a "post-regulatory" world', Current Legal Problems, 54, 103-47.

Countouris, N. and Freedland, M. (2013), 'Labour regulation and the economic crisis in Europe: challenges, response and prospects', in Heyes, J. and Rychly, L. (eds), Labour Administration in Uncertain Times. Cheltenham, UK and Northampton, MA, USA: Edward Elgar/ILO, pp. 66-94.

De Stefano, V. (2016), The Rise of the 'Just-in-Time Workforce': On-Demand Work, Crowdwork and Labour Protection in the 'Gig-Economy'. Conditions of Work and Employment Series No. 71. Geneva: ILO.

Eurofound (2016), Foundation Seminar Series 2016: The Impact of Digitalisation on Work. Dublin: Eurofound.

Gavris, M. and Heyes, J. (2019), 'Varieties of labour administration in Europe and the consequences of the Great Recession', Economic and Industrial Democracy, doi: $10.1177 / 0143831 X 19861749$.

Gunningham, N. (2010), 'Enforcement and compliance strategies', in Baldwin, R., Cave, M. and Lodge, M. (eds), The Oxford Handbook of Regulation. Oxford: Oxford University Press, pp. 120-45.

Hammerschmid, G., Van de Walle, S., Andrews, R. and Bezes, P. (eds) (2016), Public Administration Reforms in Europe: The View from the Top. Cheltenham, UK and Northampton, MA, USA: Edward Elgar.

Hayter, S. and Gammarano, R. (2015), Trends in Collective Bargaining Coverage: Stability, Erosion or Decline? Labour Relations and Collective Bargaining Policy Brief No. 1. Geneva: ILO.

Heinrich, C. (2012), 'Measuring public sector performance and effectiveness', in Peters, B.G. and Pierre, J. (eds), The Sage Handbook of Public Administration. Second edn. London: Sage, pp. 32-49.

Heyes, J. (2011), Labour Ministries and Labour Administration in Transition: Recent Developments and Future Prospects. Labour Administration and Inspection Programme. Working Document 16. Geneva: International Labour Office. 27pp. ISBN: 9789221250814/9789221250821 (web pdf).

Heyes, J. (2013), 'Flexicurity in crisis: European labour market policies in a time of austerity', European Journal of Industrial Relations, 19(3), 71-86.

Heyes, J. and Hastings T. (2017), The Practices of Enforcement Bodies in Detecting and Preventing Bogus Self-Employment. Report prepared for the European Platform 
on Undeclared Work, European Commission. 93pp. http://ec.europa.eu/social/main .jsp? catId $=1299$ \& intPageId=4875\&langId $=$ en.

Heyes, J. and Rychly, L. (eds) (2013), Labour Administration in Uncertain Times: Policy, Practice and Institutions. Cheltenham, UK and Northampton, MA, USA: Edward Elgar/ILO. 301pp.

Hyman, R. (2013), 'The role of government in industrial relations', in Heyes, J. and Rychly, L. (eds), Labour Administration in Uncertain Times: Policy, Practice and Institutions. Cheltenham, UK and Northampton, MA, USA: Edward Elgar and Geneva: ILO. 301pp.

ILO (2011), Report V - Labour Administration and Labour Inspection. International Labour Conference 100th Session. Geneva: ILO.

ILO (2013) Report V (1) Transitioning from the Informal to the Formal Economy. International Labour Conference 103rd Session. Geneva: ILO.

ILO (2016), Non-Standard Employment around the World: Understanding Challenges, Shaping Prospects. Geneva: ILO.

ILO (2018), Men and Women in the Informal Economy: A Statistical Picture. Third edn. Geneva: ILO.

ILO (2020a), Financing Gaps in Social Protection: Global Estimates and Srategies for Developing Countries in Light of the COVID-19 Crisis and Beyond. Social Protection Spotlight. Geneva: ILO.

ILO (2020b), Social Protection for Migrant Workers: A Necessary Response to the Covid 19 Crisis. Social Protection Spotlight. Geneva: ILO.

Kalleberg, A.L. (2018), Precarious Lives: Job Insecurity and Well-being in Rich Democracies. Cambridge: Polity Press.

Kjær, A.M. (2004), Governance. Cambridge: Polity Press.

Koeltz, D. (2013), 'Delivering public employment services: which model works best?', in Heyes, J. and Rychly, L. (eds), Labour Administration in Uncertain Times: Policy, Practice and Institutions. Cheltenham, UK and Northampton, MA, USA: Edward Elgar and Geneva: ILO, pp. 163-93.

Koning, P. and Heinrich, C.J. (2013), 'Cream-skimming, parking and other intended and unintended effects of high-powered, performance-based contracts', Journal of Policy Analysis and Management, 32(3), 461-83.

Kooiman, J. and Bavinck, M. (2005), 'The governance perspective', in J. Kooiman, M. Bavinck, S. Jentoft and R. Pullin (eds), Fish for Life: Interactive Governance for Fisheries. Amsterdam: Amsterdam University Press, pp. 11-24.

Köppe, S. and MacCarthaigh, M. (2019), 'Public service integration in hard times: merging unemployment benefit and labour market activation measures', Administration, 67(2), 137-60.

MacCarthaigh, M. and Hardiman, N. (2019), 'Exploiting conditionality: EU and international actors and post-NPM reform in Ireland', Public Policy and Administration, doi: 10.1177/0952076718796548.

Papadakis, K. and Ghellab, Y. (eds) (2014), The Governance of Policy Reforms in Southern Europe and Ireland: Social Dialogue Actors and Institutions in Times of Crisis. Geneva: ILO.

Randma-Liiv, T. and Kickert W. (2017), 'The impact of the fiscal crisis on public administration reforms: comparison of 14 European countries', Journal of Comparative Policy Analysis, 19(2), 155-72.

Rhodes, R. (1996), 'The new governance: governing without government', Political Studies, 44(4), 652-66. 
Rubery, J. (2015), Re-regulating for Inclusive Labour Markets. Conditions of Work and Employment Series, working paper no. 65. Geneva: ILO.

Rychly, L. (2013), 'The changing fortunes of labour administration', in Heyes, J. and Rychly, L. (eds), Labour Administration in Uncertain Times: Policy, Practice and Institutions. Cheltenham, UK and Northampton, MA, USA: Edward Elgar and Geneva: ILO, pp. 18-45.

Schippers, J. (2019), 'Labour market flexibility, self-employment and precariousness', in Conen, W. and Schippers, J. (eds), Self-Employment as Precarious Work: A European Perspective. Cheltenham, UK and Northampton, MA, USA: Edward Elgar, pp. 23-39.

Van Berkel, R., de Graaf, W. and Sirovátka, T. (2011), 'The governance of active welfare states', in Van Berkel, R., de Graaf, W. and Sirovátka, T. (eds), The Governance of Active Welfare States in Europe. Basingstoke: Palgrave Macmillan, pp. 1-21.

Vega, M.-L. (2013), 'Labour inspection systems: strengthening enforcement in times of crisis', in Heyes, J. and Rychly, L. (eds), Labour Administration in Uncertain Times: Policy, Practice and Institutions. Cheltenham, UK and Northampton, MA, USA: Edward Elgar and Geneva: ILO, 301pp.

Weishaupt, J.T. (2011), Social Partners and the Governance of Public Employment Services: Trends and Experiences from Western Europe. Geneva: ILO. http:// www.ilo.org/wcmsp5/groups/public/_ed_dialogue/—lab_admin/documents/ publication/wcms_156033.pdf(accessed 8 May 2018). 